\title{
Ophichthids (Ophichthidae: Anguilliformes) within the body cavity of marine fishes: pseudoparasites?
}

\author{
W. ISBERT ${ }^{1,2}$, F.E. MONTERO ${ }^{2}$, M. FERNÁNDEZ ${ }^{3}$, A. LOMBARTE ${ }^{1}$, M. SACANELL ${ }^{4}$ AND C. OREJAS ${ }^{1,5}$ \\ ${ }^{1}$ Instituto de Ciencias del Mar (CSIC), Pg. Maritim de la Barceloneta 37-49, 08003 Barcelona, Spain, ${ }^{2}$ Xarxa de Referència i \\ Desenvolupament en Aquicultura (Generalitat de Catalunya), Department of Animal Biology, Plant Biology and Ecology, \\ Autonomous University of Barcelona, Campus Universitari, 08193 Bellaterra, (Cerdanyola del Vallès) Barcelona, Spain, ${ }^{3}$ Unidad de \\ Zoología Marina, Instituto Cavanilles de Biodiversidad y Biología Evolutiva, Universidad de Valencia, and Fundación General de la \\ Universidad de Valencia, ${ }^{4}$ Confraria de Pescadors Artesanals de l'Estartit, Carrer Ter Vell 22, 17258 l'Estartit, ${ }^{5}$ Instituto Español de \\ Oceanografía (IEO), Promontorio de San Martín s/n, 39004 Santander, Spain
}

Three snake eels (Ophichthidae) were found in three common pandoras (Pagellus erythrinus) from the north-western Mediterranean: two in the stomach and one embedded in the body cavity. This incidence corroborates previous records of snake eels found within fish. The role of the eels as possible prey, parasites or pseudoparasites is briefly discussed.

Keywords: Apterichtus, Ophichthidae, pseudoparasitism, prey, common pandora, western Mediterranean

Submitted 8 December 2010; accepted 15 February 2011

\section{INTRDDUCTION}

Snake eels (Ophichthidae) comprise a little known family of anguilliforms (Anguilliformes) (e.g. Randall, 1967; Leiby, 1990; Casadevall et al., 2001; McCosker, 2002; Bozzano, 2003). Most of the foundation knowledge regarding true eel species (such as representatives of Ophichthidae and Synaphobranchidae) considers them free-living organisms. However, throughout the last 80 years several reports have been published of true eels found within the organs, body cavity or muscle of fish (e.g. Goode \& Bean, 1895 in Walters, 1955; Breder \& Nigrelli, 1934; Caira et al., 1997). While the authors of some of these reports suggested a parasitic life style for the involved eels, others considered the phenomenon as accidental and denoted them as cases of 'pseudoparasitism'. In this paper, the detection of a snake eel in the body cavity of common pandora, is discussed in order to shed light on the ecological role of the eels as prey or pseudoparasites reconsidering former records critically.

\section{MATERIALS AND METHDDS}

Forty-five common pandoras (Pagellus erythrinus, Linnaeus, 1758) were captured during 2008 and 2009 at the Medes Islands Marine Reserve $\left(42^{\circ} \mathrm{O}^{\prime}{ }_{51} \mathrm{~N} 3^{\circ} 13^{\prime} 19 \mathrm{E}\right.$; north-western Mediterranean), by means of gill nets and long lines at depths between 11 and $55 \mathrm{~m}$. Fish were killed and dissected within 2 to 4 hours after capture. Each fish was measured (total length (TL) in $\mathrm{cm}$ ) and weighed (total weight (TW)

Corresponding author:

W. Isbert

Email: wisbert@gmx.net and eviscerated weight (EW) in g). Fish body and viscera were deep-frozen $\left(-20^{\circ} \mathrm{C}\right)$ separately for later parasitological examination and inspection for lesions and pathological indications (e.g. cysts). Stomach and intestine contents were also collected and examined. Condition factor (CF) was calculated following the formula: $\left.\mathrm{CF}=\left[\left(\mathrm{TW}(\mathrm{g}) / \mathrm{TL}^{3}(\mathrm{~cm})\right)^{*} 100\right)\right]$ after Ricker (1975).

Three snake eels were collected from three common pandoras; one was embedded in the body cavity and two were found in stomachs. Additionally, another ophichthid was found desiccated in May 2007, washed up on La Torre beach (Moncófar, $39^{\circ} 47^{\prime} 25 \mathrm{~N} 0^{\circ} 08^{\prime} 10 \mathrm{~W}$; Castellón, western Mediterranean). All eels were identified using information in Bauchot (1986) and Mercader et al. (2003) and those collected from common pandora exemplars were preserved in $70 \%$ ethanol. Total length $(\mathrm{TL}, \mathrm{cm})$ and wet weight (WW, g) of eels were determined subsequently.

\section{RESULTS}

One female of common pandora $(36 \mathrm{~cm} \mathrm{TL})$ was captured in June 2008, and exhibited an eel $(22.2 \mathrm{~cm} \mathrm{TL}, 1.1 \mathrm{~g} \mathrm{WW})$ in its body cavity entangled in the mesentery tissue. The eviscerated weight $(\mathrm{EW}=588 \mathrm{~g})$ and $\mathrm{CF}(1.4)$ of this individual was within the range observed for other common pandora captured during the same sampling month $(34-45 \mathrm{~cm}$ TL; 495-1095 g EW; 1.1-1.4 CF; $\mathrm{N}=22$ ). Viscera of the common pandora showed a healthy aspect, and no injured organs, older cicatrizations or wounds were observed. The identified slender finless eel, Apterichtus anguiformis (Peters, 1877), exhibited a tubular anterior nostril and the number of vertebrae was 156 . It was nearly complete and in good condition, its eyes well recognizable (Figure 1) and its consistency 


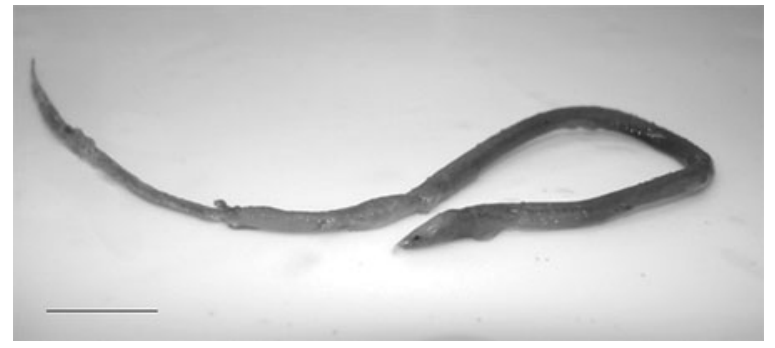

Fig. 1. Specimen of Apterichtus anguiformis found in the body cavity of a common pandora from Medes Islands (north-western Mediterranean). Scale bar: $2 \mathrm{~cm}$.

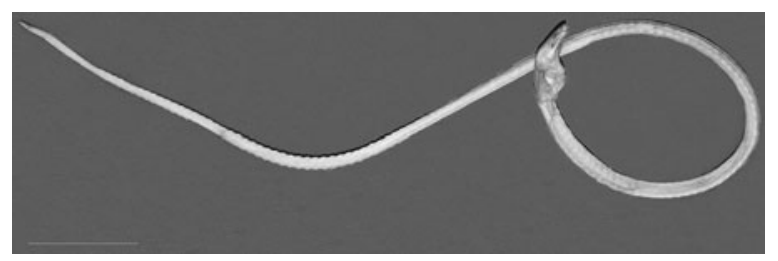

Fig. 2. Specimen of Apterichtus caecus found on La Torre beach (Moncófar, Castellón, western Mediterranean). Scale bar: $3 \mathrm{~cm}$.

was hard, slightly dehydrated, and the body cavity and inner organs appeared shrunken and cavernous. Two other small true eels, assigned as ophichthids, were found partially digested and degraded inside the stomachs of two common pandoras ( $36 \mathrm{~cm}$ TL each, $615 \mathrm{~g}$ and $553 \mathrm{~g}$ EW, 1.4 and 1.3 $\mathrm{CF}$, respectively). These ophichthids weighed $0.4 \mathrm{~g}$ and $2.5 \mathrm{~g}$ (WW) and number of vertebrae was 80 and 120 , respectively. Bodies were not flexible and with missing parts. The European finless eel Apterichtus caecus (Linnaeus, 1758) $(34.6 \mathrm{~cm}$ TL, $2.3 \mathrm{~g}$ dry weight) found in La Torre beach did not exhibit a tubular nostril and the number of vertebrae was 138
(Figure 2). It was thoroughly desiccated and nearly complete except for the inner organs.

\section{DISCUSSION}

This is the first record of an Apterichtus species within the coelom of another fish. Both, Apterichtus anguiformis and Apterichtus caecus have been recorded free living in the Mediterranean Sea (e.g. Blache \& Bauchot, 1972; Bauchot, 1986; Castriota \& Campagnuolo, 1998). Most of the published records of Apterichtus spp. are based on free-living specimens from other regions (e.g. Machida \& Ohta, 1993; McCosker \& Randall, 2005) and records of true eels inside freshly killed fish or processed fish muscle are scarce and sporadic (Table 1). As in the present case, eels have mainly been found in bodies of demersal and benthopelagic fish referring to a presumed predator-prey relationship in their habitats. It is suggested that in all cases, the eels likely entered the common pandora by being eaten. In the present study nearly $38 \%$ of common pandora examined exhibited otoliths and fishbones in the stomach content indicating fish as an important part of the diet. The indigested condition of the eel found located in the mesentery tissue may corroborate previous reports (Breder \& Nigrelli, 1934; Breder, 1953; Walters, 1955) supposing an active piercing and leaving of the digestive system.

The common pandora from which the eel was taken appeared to be healthy and its CF and EW value did not reveal any anomaly compared to other specimens. It is supposed that lesions caused by the eel penetrating the gut wall were not life threatening to the predator and finally healed. It is known that some fish (e.g. deep hooked in the throat or stomach) are able to survive large wounds, blood loss and secondary infections (Gunter \& Ward, 1961; Davis, 2002; Prince et al., 2002). As burrowing fish, ophichthids are considered to be well adapted to squeeze through narrow openings, benefiting from several morphological specializations (Smith, 1989),

Table 1. Ophichthids (Ophichthidae) and synaphobranchids (Synaphobranchidae) (Anguilliformes) reported from fish not as food items. Table is arranged according to year of publication. Accepted scientific names of species according to Froese \& Pauly (2009).

\begin{tabular}{|c|c|c|c|c|c|}
\hline Family & Species & Predator & Location & Locality & Reference \\
\hline \multirow[t]{8}{*}{ Ophichthidae } & $\begin{array}{l}\text { Ophichthus cruentifer } \\
\quad \text { (Goode \& Bean, 1896) }\end{array}$ & $\begin{array}{l}\text { Codfish and } \\
\text { halibut }\end{array}$ & - & - & $\begin{array}{l}\text { Goode \& Bean, } 1895 \text { in } \\
\text { Walters, } 1955\end{array}$ \\
\hline & $\begin{array}{l}\text { Ophichthus apicalis (Anonymous } \\
\text { (Bennett), 1830) }\end{array}$ & $\begin{array}{l}\text { Percoids (not } \\
\text { specified) }\end{array}$ & Coelom & - & $\begin{array}{l}\text { Deraniyagala, } 1932 \text { in } \\
\quad \text { Breder \& Nigrelli, } 1934\end{array}$ \\
\hline & $\begin{array}{l}\text { Myrichthys breviceps } \\
\quad \text { (Richardson, 1848) }\end{array}$ & $\begin{array}{l}\text { Epinephelus } \\
\text { itajara }\end{array}$ & Coelom & Florida & Breder \& Nigrelli, 1934 \\
\hline & $\begin{array}{l}\text { Ophichthus sp., Apterichtus sp. } \\
\text { (not identified to species) }\end{array}$ & $\begin{array}{l}\text { Lophius } \\
\text { piscatorius }\end{array}$ & - & - & $\begin{array}{l}\text { Suvorov, } 1948 \text { in Walters, } \\
1955\end{array}$ \\
\hline & $\begin{array}{l}\text { Ophichthus cruentifer } \\
\quad \text { (Goode \& Bean, 1896) }\end{array}$ & $\begin{array}{l}\text { Centropristis } \\
\text { striata }\end{array}$ & Coelom & - & Breder, 1953 \\
\hline & $\begin{array}{l}\text { Ophichthus puncticeps } \\
\text { (Kaup, 1860) }\end{array}$ & Alphestes sp. & Coelom & Bahamas & Walters, 1955 \\
\hline & $\begin{array}{l}\text { Ophichthus cruentifer } \\
\quad \text { (Goode \& Bean, 1896) }\end{array}$ & Xiphias gladius & $\begin{array}{r}\text { Stomach } \\
\text { lining }\end{array}$ & $\begin{array}{l}\text { North-western } \\
\text { Atlantic }\end{array}$ & Scott \& Crossman, 1959 \\
\hline & $\begin{array}{l}\text { Apterichtus anguiformis } \\
\quad \text { (Peters, 1877) }\end{array}$ & $\begin{array}{l}\text { Pagellus } \\
\quad \text { erythrinus }\end{array}$ & Coelom & $\begin{array}{l}\text { North-western } \\
\text { Mediterranean }\end{array}$ & Present study \\
\hline \multirow[t]{2}{*}{ Synaphobranchidae } & $\begin{array}{l}\text { Simenchelys parasiticus } \\
\quad \text { (Gill, 1879) }\end{array}$ & Halibut & Muscle & - & $\begin{array}{l}\text { Gill in Goode \& Bean, } \\
1879 \text { in Caira et al., } 1997\end{array}$ \\
\hline & $\begin{array}{l}\text { Simenchelys parasiticus } \\
\quad \text { (Gill, 1879) }\end{array}$ & $\begin{array}{l}\text { Isurus } \\
\quad \text { oxyrinchus }\end{array}$ & Heart & $\begin{array}{l}\text { North-western } \\
\text { Atlantic }\end{array}$ & Caira et al., 1997 \\
\hline
\end{tabular}


which might have led some authors to presume some species to be parasitic borers or occasional parasites (Goode \& Bean, 1895 in Walters, 1955; Suvorov 1948 in Walters, 1955). Other authors considered these incidences as 'accidents' (Breder, 1953) or 'pseudoparasitism' (Walters, 1955), which is 'the chance of entry and survival of a free living organism in the body of another' (Lincoln et al., 1998). The use of this term is inappropriate and possibly misleading, as 'pseudoparasitism' might imply real parasites accidentally acquired by a wrong host, and ending in a blind alley (e.g. Moravec, 1994). However, following the definition of 'host' in ecology (e.g. Lincoln et al., 1998), no typical host seems to exist for snake eels.

Summarizing, it is hypothesized that snake eels form a part of the diet of the common pandora and, consequently, very few ingested eels could survive being eaten and enter the body cavity where they die shortly after. Depending on the predator condition, lesions in its gut are healed and hence it survives. Considering current knowledge of ophichthid ecology and periodic records of found or caught specimens like in Moncófar the present observation is presumed to be an accidental record.

\section{ACKNDWLEDGEMENTS}

The authors thank the Universitat Autònoma de Barcelona and the Instituto de Ciencias del Mar (CSIC) for providing laboratory facilities, D. Lloris and R. Maestre for assistance in adding the study specimens to the collection of ICM, CSIC, and Mrs Yebra and Mrs Suck for the English revision of the manuscript. We are grateful to the anonymous referees for their valuable help to improve the text. This work has been supported by the BBVA foundation (Marine Protected Units in Chile and España, MAPUCHE, BIOCONo6_035). M. Fernández was supported by an $\mathrm{I}_{3}$ Contract from the Ministry of Science and Innovation of Spain. The specimens found in the common pandoras were deposited in the Collection of Biological References (CRB) of the Instituto de Ciencias del Mar (ICM-CSIC), Barcelona (Identification No.: IIPB 1/2009, IIPB 2/2009, IIPB 3/2009). The specimen from Moncófar was preserved dry in the collection of the Cavanilles Institute of Biodiversity and Evolutionary Biology of the University of Valencia (Accession Number ICBiBEApcae-080801).

\section{REFERENCES}

Bauchot M.L. (1986) Ophichthidae. In Whitehead P.J.P., Bauchot M.L., Hureau J.C., Nielsen J. and Tortonese E. (eds) Fishes of the northeastern Atlantic and the Mediterranean/poissons de l'Atlantique du nord-est et de la Mediterranée. Rome: FAO-CEE, pp. 577-585.

Blache J. and Bauchot M.L. (1972) Contribution à la connaissance des Poissons Anguilliformes de la côte occidentale d'Afrique. 13e note: les genres Verma, Apterichthus, Ichthyapus, Hemerorhinus, Caecula, Dalophis avec la description de deux genres nouveaux (Fam. Ophichthidae). Bulletin Institut Fondamental d'Afrique Noire (IFAN) 34 , série A, 692-773.

Bozzano A. (2003) Vision in the rufus snake eel, Ophichthus rufus: adaptive mechanisms for a burrowing life-style. Marine Biology 143, $167-174$.
Breder C.M. Jr (1953) An ophichthid eel in the coelom of a sea bass. New York Zoological Society Zoologica 38, 201-202.

Breder C.M. Jr and Nigrelli R.F. (1934) The penetration of a grouper's digestive tract by a sharp-tailed eel. Copeia 1934, 162-164.

Caira J.N., Benz G.W., Borucinska J. and Kohler N.E. (1997) Pugnose eels, Simenchelys parasiticus (Synaphobranchidae) from the heart of a shortfin mako, Isurus oxyrinchus (Lamnidae). Environmental Biology of Fishes 49, 139-144.

Casadevall M., Muñoz M., Carrasson M. and Matallanas J. (2001) The reproductive cycle of Ophichthus rufus (Anguilliformes) in the northwest Mediterranean. Cybium 25, 53-65.

Castriota L. and Campagnuolo S. (1998) First record of Apterichtus anguiformis (Anguilliformes, Ophichthidae) in the Southern Tyrrhenian Sea. Cybium 22, 198-200.

Davis M.W. (2002) Key principles for understanding fish bycatch discard mortality. Canadian Journal of Fisheries and Aquatic Science 59, $1834-1843$.

Froese R. and Pauly D. (eds) (2009) Fishbase. World Wide Web electronic publication. www.fishbase.org, version (accessed November 2009).

Gunter G. and Ward J.W. (1961) Some fishes that survive extreme injuries, and some aspects of tenacity of life. Copeia 1961, 456-462.

Leiby M. (1990) Ophichthidae. In Quero J.C., Hureau J.C., Karrer C., Post A. and Saldanha L. (eds) Check-list of the fishes of the eastern tropical Atlantic (CLOFETA). Lisbon: JNICT; Paris: SEI; Paris: UNESCO, pp. $176-192$.

Lincoln R.J., Boxshall G.A. and Clark P.F. (eds) (1998) A dictionary of ecology, evolution and systematics. 2nd edition. Cambridge: Cambridge University Press.

Machida Y. and Ohta S. (1993) Second specimen of the snake-eel, Apterichtus moseri (Ophichthinae, Ophichthidae). Japanese Journal of Ichthyology 40, 103-106.

McCosker J.E. (2002) Anguilliformes: Ophichthidae. Snake eels (shrimp eels, worm eels, and sand eels). In Carpenter K.E. (ed.) The living marine resources of the Western Central Atlantic. Volume 2: Bony fishes part 1 (Acipenseridae to Grammatidae). FAO Species Identification Guide for Fishery Purposes and American Society of Ichthyologists and Herpetologists Special Publication 5, pp. 724-733.

McCosker J.E. and Randall J.E. (2005) Notes on the snake eels of the genera Apterichtus and Ichthyapus (Anguilliformes: Ophichthidae) of the Central and South Pacific, with the description of a new species. Zootaxa 800, 1-11.

Mercader L., Lloris D. and Rucabado J. (2003) Tots els peixos del Mar Català. Diagnosis i claus d'identificació. 2nd edition. Barcelona: Institut d'Estudis Catalans.

Moravec F. (1994) Parasitic nematodes of freshwater fishes of Europe. Dordrecht, The Netherlands, Boston and London: Kluwer Academic Publishers.

Prince E.D., Ortiz M. and Venizelos A. (2002) A comparison of circle hook and ' $J$ ' hook performance in recreational catch-and-release fisheries for billfish. American Fisheries Society Symposium 30, 66-79.

Randall J. E. (1967) Food habits of reef fishes of the West Indies. Studies in Tropical Oceanography 5, 665-847.

Ricker W.E. (1975) Computations and interpretations of biological statistics of fish populations. Bulletin of the Research Board of Canada $191,1-382$.

Scott W.B. and Crossman E.J. (1959) The snake eel, Omochelys cruentifer, in Canadian Atlantic waters. Copeia 1959, 344-345. 
Smith D.G. (1989) Family Congridae. In Böhlke E.B. (ed.) Fishes of the western North Atlantic. New Haven, CT: Sears Foundation for Marine Research, pp. 460-567.

and

Walters V. (1955) Snake-eels as pseudoparasites of fishes. Copeia 1955, $146-147$.
Correspondence should be addressed to:

W. Isbert

Unitat de Zoologia

Departamento Biologia Animal

Biologia Vegetal i Ecologia

Universitat Autònoma de Barcelona, 08193 Cerdanyola del

Vallès, Barcelona, Spain

email: wisbert@gmx.net 